\title{
The Situation Regarding School Canteen and Physical Activities among a Sample of Primary and Preparatory School Children in Egypt
}

\author{
Gihan A Fouad - Salwa M Salah - May K Mettar - Hoda M El Gezery - \\ Asmaa E Mostafa and Asmaa S Abed-El-Wahed \\ National Nutrition Institute \\ Corresponding author: Asmaa E MostafaＥmail: dr_asmaa707@Yahoo.com
}

\section{ABSTRACT:}

$N$ on-communicable diseases (NCDs) come via (unhealthy diet, /physical inactivity, tobacco use and harmful use of alcohol); all increase the risk of dying from NCDs. Children consume approximately half of their total daily amount of energy at school. This work designed to get a baseline data on the condition with reference to school canteen and physical activities between primary and preparatory schools. The study was conducted among 1361 school children age (6 y-13 y) randomly selected from schools in four governorates: Cairo, Qalyobia, Menofia and Giza. Two types of questionnaire were done during the study; which interview was conducted to the school children, and qualitative type (focus group discussion) for school children and teachers responsible for nutrition in the school. Results revealed that the majority of the sample used to buy from school canteens (1294). Food from canteen was Low nutritious value high energy. However, these recommendations were achieved by only (37.1\%) of study sample, nearly two thirds (63.9\%) of the sample didn't practice any physical activities, while $14 \%$ and $10.7 \%$ of them practice physical activity once and twice weekly respectively. One quarter of the sample (25.4\%) stay in front of TV or computer less than 1 hour daily, and 58\% of them stay 2 hours daily. Conclusion: The present study shows that low nutritious value high energy density food items represent the commonly consumed food brought from school canteens. The practice of physical activity is very little, and in case of practicing, it is practiced infrequently.

Key words: School - canteen - physical activity - NCDs 


\section{INTRODUCTION:}

Non - communicable diseases (NCDs) are also known as chronic diseases. There are four main types of NCDs: cardiovascular diseases (e.g., heart attack and stroke); chronic respiratory diseases (e.g., chronic obstructive pulmonary disease and asthma); diabetes; and cancers (WHO, 2018). In2018 Non communicable diseases (NCDs) kill 41 million people each year, equivalent to $71 \%$ of all deaths globally. Tobacco use, physical inactivity, the harmful use of alcohol and unhealthy diets all increase the risk of dying (WHO, 2018). Risk factors of these NCDs are smoking tobacco; nutrition; physical activity; alcohol consumption; and poor hygiene (Parry et al., 2011). Children are not immune to this burden of NCD. Overweight children, and obesity and type 2 diabetes in children and adolescents are increasing problems. Globally, nearly 22 million children under 5 years of age are overweight. Overweight and obese children are likely to stay obese in adulthood and more likely to develop NCDs like diabetes and cardiovascular diseases in Adulthood (Alberto et al., 2018). In response to the growing burden of NCDs and to reduce the impact of major risk factors such as unhealthy diet and physical inactivity, the World Health Assembly adopted the "Global Strategy on Diet, Physical Activity and Health, which Stated that "School policies and programs should support the adoption of healthy diets and physical activity (WHO, 2015).

Schools are a prime location for NCDs prevention through life skills education and providing a supportive healthy environment for children to support the development and application of a healthy lifestyle (WHO, 2017). Schools are encouraged to provide students with daily physical education and should be equipped with appropriate facilities and equipment. WHO recommends that children and adolescents aged 5-17 years require at least 60 minutes of moderate or vigorous physical activity daily, (WHO, 2018). Governments are encouraged to adopt policies that support healthy diets at school and limit the availability of products high in salt, sugar and fats (WHO, 2005). To avoid unhealthy weight gain, total dietary fat should not 
exceed $30 \%$ of total energy intake ((Food and Agriculture Organization, 2010). Sugar intake should be less than $10 \%$ of total energy intake, keeping salt intake to less than $5 \mathrm{~g}$ per day is also recommended to prevent hypertension and reduce the risk of heart disease and stroke in adults and young people (WHO, 2012 and 2015). As alcohol consumption is one of the risk factors of NCDs, WHO states that alcohol use begins in adolescence and that $25 \%$ of 13-15-year-old report having an alcoholic drink (WHO, 2015). Starting an effective school policy to promote healthy eating and physical activity requires national strategic leadership). Enabling young people to become aware of these guidelines, through life skills education, is a crucial preventative measure against the onset of NCDrelated conditions and concerns.

\section{AIM OF THE STUDY}

This work was designed to get a baseline data on the situation regarding school canteen and physical activities among primary and preparatory school age children $(6 \mathrm{y}-13$ y). Help to develop a national guideline for school feeding canteens and to develop physical activity policy in schools.

\section{SUBJECT AND METHODS}

A cross section of study was conducted among 1361 as total schoolchildren randomly selected from a sample of primary and preparatory schools selected from urban and rural sites in different governorates while the majority of the sample used to buy from school canteens (1294). Cairo as a capital (5 schools; 4 primary and one school for special need children). Qalyobia (5 schools; all are primary schools), and Menofia (4 schools; 3 primary and one preparatory school) as a Lower Egypt. While Giza as an Upper Egypt (6 schools; 5 primary and 1 preparatory school). All the primary schools received fortified biscuits with iron as school feeding program, while none of the preparatory schools had school feeding program for their children.

Two types of questionnaire were done during this study; quantitative type in which interview was conducted to the schoolchildren by investigators, and qualitative type (focus group discussion) for schoolchildren and 
for teachers responsible for nutrition in the school.

\section{Statistical analysis}

Statistical analysis of the results by using computer program (SPSS), Independent descriptive statistics in the form of frequencies and percentages for qualitative variables, F-test and one-way analysis of variance (ANOVA) were used, the difference was considered significant at $(P$-value $<0.05)($ Zar, 1984)

\section{RESULTS}

Results in the table (1) revealed that the majority of the sample (91.1\%) bought food items from school canteens. Cairo is the highest percent bought food from school cafeterias, while Qalubeya is the lowest governorate. There was a significant difference between all governorates $(\mathrm{P}<$ $0.05)$.

Many reasons in the table (2) as they stated $27.8 \%$ of them bought following their peers with no significant difference in all governorates. $62.2 \%$ of them bought from canteen as they have money. $15 \%$ of them bought because they did not like home food, $2.9 \%$ of them bought as they did not like home sandwiches, and
$0.7 \%$ of them bought according to TV advertisement.

In the table (3) about onethird of the sample bought daily from canteen (38.6\%), one-third of the sample bought three times a week from canteen (35.6\%), and around one-fourth of the sample (25.8\%) bought twice weekly.

Table (4) represented that the chips most commonly consumed by nearly two-thirds of the school children (63.9\%) followed by biscuits $57.9 \%$, cakes $46.4 \%$, fresh juice $36.2 \%$, pancakes $6.5 \%$, chocolate $20.2 \%$, puff corn $21.6 \%$, soft drinks $17.1 \%$, sandwiches $3.4 \%$, milk $3.4 \%$, candies $6.1 \%$, and peanuts $2.4 \%$ with significant difference between governorates for all item except cake and candy.

Results in table (5) showed that only $8.3 \%$ of the surveyed schoolchildren did not buy food from the school canteen: $(5.7 \%)$ came from food home and $2.6 \%$ did not have money to buy. There was a significant difference between all governorates for both items in the table.

The distribution of school feeding program (biscuits) in the table (6) affected that the percent 
or the pattern of buying from canteens as $66.9 \%$ of the sample did not buy from the canteen on the day the biscuits were versus $33.1 \%$ were bought.

About $28.6 \%$ of the samples know their weight and $8.3 \%$ know their height. $42.6 \%$ of the sample did not know their body picture, $28.2 \%$ know their body form were good, $21.2 \% \%$ know their body style were thin and $8 \%$ know their body image were overweight in a table (7).

Table (8) results showed that $65.7 \%$ of sample did not practice physical activity not once for more than $60 \mathrm{~min}$ a day a week. $13.4 \%$ practiced physical activity once a week, $8.3 \%$ practiced physical activity twice a week. $5.3 \%$ practiced physical activity three times a week, 3.6\% practiced physical activity five times a week, $1.5 \%$ practiced physical activity four times a week, $1.4 \%$ practiced physical activity seven times a week's and $0.9 \%$ of sample practiced physical activity six times a week.

Results in table (9)
demonstrated that $34.9 \%$ of
children of school did not walk to
school in the past 7 days. $49.8 \%$

walk five day for the week, $4.4 \%$ walk three day for the week, $4.1 \%$ walk one day for the week, $2.6 \%$ walk two day for the week, $1.8 \%$ walk four day for the week, $1.6 \%$ walk six day for the week and $0.8 \%$ walk seven day for the week.

Table (10) showed that $77.3 \%$ of a sample practiced physical activity class one time per week, while $17.5 \%$ did not practice physical activity class one time per week and $4.1 \%$ of a sample practiced physical activity class two time per week.

Table (11) showed that 44 $\%$ of students did not learn the benefits of physical activity at school, while $35.4 \%$ learn the benefits. There are a significant difference between all samples of governorates $(\mathrm{P}<0.000)$.

Results in table (12) demonstrated that $57.7 \%$ of sample practiced physical activity for 1-2 hours, $25.9 \%$ practiced physical activity less than 1 hour, $13.8 \%$ practiced physical activity for 3-4 hours, and $2.2 \%$ practiced physical activity for 5-6 hours with significant difference between all specimen $(\mathrm{P}<0.000)$. 


\section{DISCUSSION:}

Non-communicable diseases (NCDs) kill 41 million people each year, equivalent to $71 \%$ of all deaths globally. The increase in the mortality burden from NCDs can be due to the rise in the risk factors (WHO, 2018). Tobacco use, physical inactivity, the harmful use of alcohol, and unhealthy diets all increase NCDs (Matthews, 2018). The school canteens play a crucial role in ensuring the nutritional well-being of children. Regular consumption of unhealthy food items purchased from the school canteens may add to the existing burden of childhood obesity and its complication NCDs (Puva, 2019). Several studies have already highlighted the influence of school canteens on children's dietary habits and body weight. The present results revealed that the majority of the children bought from school canteens either primary school or preparatory school children because of many reasons as buying following their peers or they have and some did not bring food from home. Different low nutritious value food items found in the school canteen in different four governorates in Egypt (Cairo, Qalyobia, Menofia, and Giza). The commonly consumed food items in school canteens; was chips represent the most commonly consumed being bought by nearly two thirds of the school children $(63.9 \%)$ followed by biscuits $57.9 \%$, cakes $46.4 \%$, fresh juice $36.2 \%$, chocolate $20.2 \%$, corn $21.6 \%$, soft drinks $17.1 \%$, sandwiches $3.4 \%$, milk $2.5 \%$, and peanuts $2.2 \%$. Only $8.3 \%$ of the surveyed schoolchildren did not buy food from the school canteen. The present results consistent with (Khalid, 2018) who revealed that the most commonly food items sold in the canteen were energydense snacks such as cakes and muffins $(98.7 \%)$, confectionaries (96\%), biscuits and cookies (93.4\%), and chips (52.6\%).

Condon et al., (2009) found that $44 \%, 23 \%$, and $20 \%$ of 494 high schools offered doughnuts, biscuits, and muffins, respectively. Children consume on average, $40 \%$ of the total amount of energy during school hours (Bell and Swinburn., 2004) and often the types of foods consumed are high in saturated fat, added sugar and salt (e.g., waffles, chocolate milk, iced teas, cakes and sausages) (Chortatos et al.,: 2018). 
Togoo et al., (2012) found that $87 \%$ of the food items available in the school canteens were energydense foods such as confectionaries, chips, cakes, cookies, pudding, and ice cream. The present study found that most of the food items in the school canteen foods did not follow the recommendation of the (WHO, 2015). The results showed that the compliance score of most of the selected schools in Riyadh with the requirements of the Saudi policy regarding "Meals and beverages offered in school canteens" ranged from_25\% to 75 a similar trend was found in the Gulf region. According to the World Cancer Research Fund., the compliance of Kuwaiti public schools with banned foods monitored by the Kuwaiti Ministry of Education was not high (WCR, 2015). The present study found that none of the selected schools in the study follows the recommendations for the percentage of total energy, fat, and saturated fat in foods offered in school canteens. Results showed that foods available in the selected schools in Riyadh (Khalid, 2018) contain more energy, fat, and saturated fat than what is recommended by IOM standards.
These results concur with a study conducted in the United States that $73.8 \%, 36.2 \%$, and $71.2 \%$ of students aged5-13yearsselected foods that exceeded the upper limit of the IOM recommendations with total energy, fat, and saturated fat, respectively (Martin et, al: 2010)).

In France, a study on school meals concluded that lunchtime food intake differed between the school canteen and other locations. Some intakes at school canteens were more by the regulations (more fruit and vegetables, fish and dairy products, and fewer sandwiches, soft drinks, chocolate and confectionery), whereas others highlighted improvement needs (more sweet biscuits and pastries, ice cream and dairy desserts, pizzas and salty pastries) (Carine et al., 2015). These findings found great supportive evidence from previous studies of school meals (Prynne et al., 2013) and (Fahlman et al., 2008). The present study revealed that school meals affect the buying capacity from the canteen.

Regular physical activity helps children and adolescents develop healthy behaviors, which they can sustain throughout their 
lives. Furthermore, participating in regular physical activity increases muscle and bone strength and maintains a healthy weight. It also improves psychological well-being and reduces symptoms of depression and anxiety (Landry, 2012). World Health Organization (WHO) has set recommendations for children aged 5-17 years to practice moderate to vigorous physical activity at least $60 \mathrm{~min}$ per day (WHO, 2008).

However, these recommendations were achieved by only $(37.1 \%)$ of our study sample. The majority of the sample $(77 \%)$ regularly attended the physical activity class, while $14.2 \%$ of them did not attend the class without reason. Only $35 \%$ of the schoolchildren know the benefits of practicing physical activity. Nearly two-thirds (63.9\%) of the sample did not practice any physical activities, while $14 \%$ and $10.7 \%$ of them practice physical activity once and twice weekly respectively. However, $34.2 \%$ of the sample did not walk and $52.5 \%$ of them walk and/or ride bicycles for 5 days every week. One-quarter of the sample (25.4\%) stay in front of a TV or computer for less than 1 hour daily, and 58\% of them stay 2 hours daily.

These results were in agreement with a previous Egyptian study, about 43\%) practiced physical activity less than three times per week (less than the recommended by WHO). On the other hand, sedentary behaviors were much commoner and for prolonged periods. The majority of students $(68.4 \%)$ watched TV for at least 3 hours daily and about $53.5 \%$ of the students reported playing computer games at least one hour daily (El-Gilany and EL-Masry., 2011).

Similarity found among Saudi Arabian, nearly 63\% of them did not meet the daily physical activity guidelines (AlHazzaa, 2011).

The present result was supported by another USA study in the period from 1999-2009 showed that the adolescence increased their average amount of time spent viewing TV from 3 hours 45 minutes to 4 hours 30 minutes per day. Moreover, daily computer use also increased in the same period from 27 minutes to 1 hour 29 minutes (Rideout. 2010). 
Reports suggest that children who spend too much time at the computer or watch more than ten hours of TV per week are missing important activities like playing with friends, reading or going outside (Strasburger, 2013). These children are at increased risk for social isolation, bad academic performance, aggressive behavior (Manz, 2014)

\section{CONCLUSION}

Low nutritious value high energy density food items represented the commonly consumed food bought from school canteens. The practice of physical activity was very low and practiced infrequently. WHO has set recommendations for children aged 5-17 years to practice moderate to vigorous physical activity at least $60 \mathrm{~min}$ per day. However, these recommendations were achieved by only $(37.1 \%)$ of our study sample nearly two-thirds (63.9\%) of the sample did not practice any physical activities, while $14 \%$ and $10.7 \%$ of them practiced physical activity once and twice weekly respectively. One-quarter of the sample, $(25.4 \%)$ stayed in front of the TV or computer less than 1 hour daily, and $58 \%$ of them stayed 2 hours daily.

\section{RECOMMENDATION}

Setting National

Guidelines for school canteens in Egypt is an essential step for better and healthier feeding in the schools encouraging physical activity.

\section{REFERENCES}

Alberto M; Ortega Hinojosa Kara E; MacLeod; John Balmes and Micha $E$ (2018):

Influence of school environments on childhood obesity in California. Environmental Research Volume 166, October, Pages 100-107

\section{Al-Hazzaa HM; Abahussain NA; Al-Sobayel HI; Qahwaji DM and Musaiger AO (2011): \\ Physical activity, sedentary behaviors and dietary habits among Saudi adolescents relative to age, gender and region. Int $J$ Behav Nutr Phys Act. 8(1):140.}

Bell, A.C. and Swinburn, B.A. (2004): 
What are the key food groups to target for preventing obesity and improving nutrition in schools? Eur. J. Clin. Nutr., 58, 258-263.

Carine Dubuisson; Sandrine Lioret Dufour Ariane and Gloria Calamassi- Tran (2015):

The relationship between school lunch attendance and the food intakes of French schoolchildren aged 3-17 years .J. Public Health Nutrition .18(09):111

Chortatos A; Terragni L; Henjum S; Gjertsen $\mathrm{M}$; Torheim LE; Gebremariam K (2018):

Consumption habits of school canteen and noncanteen users among Norwegian young adolescents: A mixed method analysis. $B M C$ Pediatr. 18, 328.

Condon EM; Crepinsek MK and Fox MK (2009):

School Meals: Types of Foods Offered to and Consumed by Children at Lunch and Breakfast. J.Am. Diet.Assoc. 109(2): S67-78.

El-Gilany AH and El-Masry R (2011):

Overweight and obesity among adolescent school students in Mansoura, Egypt. Childhood Obesity (Formerly Obesity and Weight Management). 7(3):215-222.

Fahlman MM; Dake JA; McCaughtry $\mathbf{N}$ and Martin $J$ (2008):

A pilot study to examine the effects of a nutrition intervention on nutrition knowledge, behaviors, and efficacy expectations in middle school children. $J$ Sch Health. 78(4):216222.

Food and Agriculture Organization of the United Nations (2010):

Fats and fatty acids in human nutrition: report of an expert consultation. FAO Food and Nutrition Paper 91. Rome (http://www.fao.org/3/a- 
i1953e.pdf, accessed 20

December 2019).

Khalid Aldubayan and Mary Murimi (2018):

Compliance with school nutrition policy in Riyadh, Saudi Arabia: a quantitative study. Some rights reserved. This work is available under the $\mathrm{CC}$ BY -NC - SA 3.0 IGO license (https:// creativecommons.org/licenses/by-n c- sa/3.0/igo)

\section{Landry BW (2012):}

Driscoll SW. Physical activity in children and adolescents. $P M$ \& R.; 4 (11):826-832

Manz K; Schlack R; PoethkoMuller C; Mensink G; Finger J and Lampert $T$ (2014):

Physical activity and electronic media use in children and adolescents: results of the KiGGS study: first follow-up (KiGGS wave 1)].

Bundesgesundheitsblatt, Gesundheit for schung, Gesundheit schutz.; 57 (7): 840-848.
Martin CK; Thomson JL; LeBlanc MM; Stewart TM; Newton RL and Han H (2010):

Children in school cafeterias select foods containing more saturated fat and energy than the Institute of Medicine recommendations. J. Nutr. 140(9):1653-1660.

Matthews C (2018):

Non-communicable diseases in the Caribbean: the new challenge for productivity and growth. Available rom: http://documents.worl dbank.org/curated/en/7864 71468223480691/pdf/7859 60WP07-0No00Box37734 9B00PUBLIC0.pdf Access ed 5 March 2018

\section{Parry C; Patra J and Rehm J} (2011):

Alcohol consumption and non-communicable diseases: epidemiology and policy implications. Addiction (Abingdon, England): 106(10):1718-24

\section{Prynne CJ; Handford C; Dunn $V$ and Bamber D (2013):}


The quality of midday meals eaten at school by adolescents; school lunches compared with packed lunches and their contribution to total energy and nutrient intakes. Public Health. Nutr. 16(6):11181125.

\section{Purva Sharma (2019):}

Review of the Nutritional Quality of School Canteen Foods in South Asia Article in Indian. J. of Public Health Research and Development . 10(7):1600

Rideout VJ; Foehr UG and Roberts DF (2010):

Generation M [superscript 2]: Media in the Lives of 8to 18 -Year-Olds. Henry J. Kaiser Family Foundation.

Strasburger VC; Hogan MJ and Mulligan DA (2013):

Children, adolescents, and the media. Pediatrics. 132(5):958-961.

Togoo RA; Meer Z; Kandlaya R; Yaseen SM; Al-Shehri TD and Al-Ghamdi HG (2012):
Availability of Cariogenic Foods in Primary School Canteens of Abha City, Saudi Arabia: A CrossSectional Study. World. 3(3):239-42.

World Cancer Research (WCR) (2015):

Offer healthy foods; physical activity school canteen (https: / / www. wcrf.org/int/policy/nourish ing-framework/offer-

World Health Organization (WHO) (2005):

Preventing chronic diseases, a vital investment. Geneva, World Health Organization, 2005.

\section{World Health Organization} (WHO). (2008):

School policy framework: implementation of the WHO global strategy on diet, physical activity and health.

World Health Organization (WHO): (2012):

Guideline: Sodium intake for adults and children. Geneva: (https:// www. who.int/nutrition/publicatio 
ns/guidelines/sodium_intak

e_printversion.pdf, acessed 20 December 2019).

\section{World Health Organization.} (2015):

Guideline: Sugars intake for adults and children. Geneva: (https:// www. who.int/nutrition/publicatio ns/guidelines/sugars_intake len/, accessed 20 December 2019). Prevention of noncommunicable diseases Life skills education school handbook 44.

\section{World Health Organization (WHO) (2017):}

Health Promoting School: an effective approach for early action on NCD risk factors. Geneva: (http: // www.who.int/healthpromot ion/publications/ healthpromotion-school/ accessed 20 December 2019).

\section{World Health Organization (WHO) (2018):}

Noncommunicable diseases. Geneva noncommunicable - diseases, accessed 20 December 2019). (https:// www. who.int/ news - room / fact- sheets /detail/

\section{Zar JH (1984):}

Biostatistician analysis. 2thedn. Prencice -Hall, Englewood Cliffs. N.J., pp. 196-198. 
Table (1): Number and percent of students buying from the canteen

\begin{tabular}{|c|c|c|c|c|c|c|c|c|c|c|c|}
\hline \multirow[t]{2}{*}{$\begin{array}{l}\text { Sample } \\
\text { number }\end{array}$} & \multicolumn{2}{|c|}{$\begin{array}{c}\text { Qalubeya } \\
\text { (320) }\end{array}$} & \multicolumn{2}{|c|}{$\begin{array}{l}\text { Giza } \\
(390)\end{array}$} & \multicolumn{2}{|c|}{$\begin{array}{l}\text { Cairo } \\
(258)\end{array}$} & \multicolumn{2}{|c|}{$\begin{array}{c}\text { Monofeya } \\
\text { (326) }\end{array}$} & \multicolumn{2}{|c|}{$\begin{array}{l}\text { Total } \\
\text { (1294) }\end{array}$} & \multirow[t]{2}{*}{$\begin{array}{c}P \\
\text { value }\end{array}$} \\
\hline & No & $\%$ & No & $\%$ & NO & $\%$ & No & $\%$ & No & $\%$ & \\
\hline $\begin{array}{lr}\begin{array}{l}\text { Number } \\
\text { percent }\end{array} & \begin{array}{r}\text { and } \\
\text { of }\end{array} \\
\text { students } & \\
\text { buying } & \text { food } \\
\text { item } & \text { from } \\
\text { school } & \\
\text { canteen } & \end{array}$ & 272 & $(85)$ & 356 & $(91.3)$ & 247 & $(95.7)$ & 311 & $(95.3)$ & 1186 & $(91.6)$ & 0.004 \\
\hline
\end{tabular}


Table (2): Causes of buying from canteen

\begin{tabular}{|c|c|c|c|c|c|c|c|c|c|c|c|}
\hline & \multicolumn{2}{|c|}{ Qalubeya } & \multicolumn{2}{|c|}{ Giza } & \multicolumn{2}{|c|}{ Cairo } & \multicolumn{2}{|c|}{ Monofeya } & \multicolumn{2}{|c|}{ Total } & \multirow[t]{2}{*}{$P$ value } \\
\hline & No & $\%$ & No & $\%$ & No & $\%$ & No & $\%$ & No & $\%$ & \\
\hline As my friend & 74 & 25.1 & 106 & 29.7 & 65 & 26.1 & 95 & 29.5 & 340 & 27.8 & 0.468 \\
\hline $\begin{array}{l}\text { Have money got } \\
\text { many from home }\end{array}$ & 179 & 60.7 & 183 & 51.3 & 163 & 65.5 & 236 & 73.3 & 761 & 62.2 & 0.000 \\
\hline $\begin{array}{l}\text { Don't like home } \\
\text { food }\end{array}$ & 38 & 12.9 & 63 & 17.6 & 21 & 8.4 & 61 & 18.9 & 183 & 15 & 0.002 \\
\hline $\begin{array}{l}\text { Don't like home } \\
\text { sandwiches }\end{array}$ & 14 & 4.7 & 15 & 4.2 & 3 & 1.2 & 4 & 1.2 & 36 & 2.9 & 0.011 \\
\hline TV advertisements & 2 & 0.7 & 7 & 2 & 0 & 0 & 0 & 0 & 9 & 0.7 & 0.009 \\
\hline Others & 41 & 13.9 & 48 & 13.4 & 36 & 14.5 & 21 & 6.5 & 146 & 11.9 & 0.006 \\
\hline
\end{tabular}


Table (3): Frequency of buying from the canteen per week

\begin{tabular}{|c|c|c|c|c|c|c|c|c|c|c|c|}
\hline & \multicolumn{2}{|c|}{ Qalubeya } & \multicolumn{2}{|c|}{ Giza } & \multicolumn{2}{|c|}{ Cairo } & \multicolumn{2}{|c|}{ Monofeya } & \multicolumn{2}{|c|}{ Total } & P value \\
\hline & No & $\%$ & No & $\%$ & No & $\%$ & No & $\%$ & No & $\%$ & 0.002 \\
\hline Daily & 106 & 35.9 & 118 & 33.1 & 108 & 43.5 & 140 & 43.5 & 472 & 38.6 & \\
\hline Three or more & 120 & 40.7 & 122 & 34.2 & 90 & 36.3 & 103 & 32 & 435 & 35.6 & \\
\hline Once or twice & 69 & 23.4 & 117 & 32.8 & 50 & 20.2 & 79 & 14.5 & 315 & 25.8 & \\
\hline
\end{tabular}


Table (4): Type of snacks they buy from the canteen

\begin{tabular}{|c|c|c|c|c|c|c|c|c|c|c|c|}
\hline \multirow[t]{2}{*}{ Food } & \multicolumn{2}{|c|}{$\begin{array}{c}\text { Qalubeya } \\
\text { (320) }\end{array}$} & \multicolumn{2}{|c|}{$\begin{array}{l}\text { Giza } \\
(390)\end{array}$} & \multicolumn{2}{|c|}{$\begin{array}{l}\text { Cairo } \\
\text { (258) }\end{array}$} & \multicolumn{2}{|c|}{$\begin{array}{c}\text { Monofeya } \\
(\mathbf{3 2 6})\end{array}$} & \multicolumn{2}{|c|}{ Total } & \multirow[t]{2}{*}{ P value } \\
\hline & No & $\%$ & No & $\%$ & No & $\%$ & No & $\%$ & No & $\%$ & \\
\hline Biscuit & 163 & 50.9 & 176 & 45.1 & 125 & 48.4 & 285 & 87.4 & 249 & 57.9 & 0.000 \\
\hline Cake & 152 & 47.5 & 176 & 45.1 & 105 & 40.7 & 167 & 51.2 & 600 & 46.4 & 0.077 \\
\hline Pie & 18 & 5.6 & 62 & 15.9 & 7 & 2.7 & 12 & 3.7 & 99 & 7.7 & 0.000 \\
\hline Chocolate & 76 & 23.8 & 66 & 16.9 & 27 & 10.5 & 92 & 28.2 & 261 & 20.2 & 0.000 \\
\hline Chips & 223 & 69.7 & 268 & 68.7 & 170 & 65.9 & 166 & 50.9 & 827 & 63.9 & 0.000 \\
\hline Pop corn & 104 & 32.5 & 71 & 18.2 & 38 & 14.7 & 67 & 20.6 & 280 & 21.6 & 0.000 \\
\hline
\end{tabular}


Con.

\begin{tabular}{|c|c|c|c|c|c|c|c|c|c|c|c|}
\hline Sandwiches & 6 & 1.9 & 9 & 2.3 & 5 & 1.9 & 24 & 7.4 & 44 & 3.4 & 0.000 \\
\hline Soda & 25 & 7.8 & 72 & 18.5 & 47 & 18.2 & 77 & 23.6 & 221 & 17.1 & 0.000 \\
\hline Juice & 76 & 23.8 & 127 & 32.6 & 86 & 33.3 & 180 & 55.2 & 469 & 36.2 & 0.000 \\
\hline Yogurt & 0 & 0 & 3 & 0.8 & 1 & 0.4 & 4 & 1.2 & 8 & 0.6 & 0.228 \\
\hline Milk & 5 & 1.6 & 35 & 9 & 4 & 1.6 & 0 & 0 & 44 & 3.4 & 0.000 \\
\hline Candy & 22 & 6.9 & 27 & 6.9 & 8 & 3.1 & 22 & 6.7 & 79 & 6.1 & 0.166 \\
\hline Cotton candy & 2 & 0.6 & 7 & 1.8 & 1 & 0.4 & 1 & 0.3 & 11 & 0.9 & 0.106 \\
\hline Benut & 1 & 0.3 & 21 & 5.4 & 9 & 3.5 & 0 & 0 & 31 & 2.4 & 0.000 \\
\hline Chick peas & 3 & 0.9 & 8 & 2.1 & 3 & 1.2 & 0 & 0 & 14 & 1.1 & 0.07 \\
\hline Others & 70 & 21.9 & 39 & 10 & 50 & 19.4 & 64 & 19.6 & 223 & 17.2 & 0.000 \\
\hline
\end{tabular}


Table (5): Causes of not buying from canteen

\begin{tabular}{|c|c|c|c|c|c|c|c|c|c|c|c|c|}
\hline & \multicolumn{2}{|c|}{ Qalubeya } & \multicolumn{2}{|c|}{ Giza } & \multicolumn{2}{|c|}{ Cairo } & \multicolumn{2}{|c|}{ Monofya } & \multicolumn{2}{|c|}{ Total } & \multirow{2}{*}{$\begin{array}{c}\begin{array}{c}\text { Total did } \\
\text { not buy food }\end{array} \\
\%\end{array}$} & \multirow[t]{2}{*}{$P$ value } \\
\hline & No & $\%$ & No & $\%$ & No & $\%$ & No & $\%$ & No & $\%$ & & \\
\hline Got food from home & 28 & 8.8 & 27 & 7 & 9 & 3.4 & 10 & 3.6 & 74 & 5.7 & 8.3 & 0.000 \\
\hline No pocket money & 20 & 6.2 & 7 & 1.7 & 2 & 0.8 & 5 & 1.1 & 34 & 2.6 & & \\
\hline
\end{tabular}

Table (6) Do you buy from the canteen on biscuit distribution day?

\begin{tabular}{|c|c|c|c|c|c|c|c|c|c|c|}
\hline \multirow{2}{*}{} & \multicolumn{2}{|c|}{ Qalyobya } & \multicolumn{2}{|c|}{ Giza } & \multicolumn{2}{c|}{ Cairo } & \multicolumn{2}{c|}{ Monofya } & \multicolumn{2}{c|}{ Total } \\
\cline { 2 - 11 } & No & $\%$ & No & $\%$ & No & $\%$ & No & $\%$ & No & $\%$ \\
\hline Yes & 120 & 37.5 & 164 & 42.1 & 96 & 37.2 & 48 & 14.7 & 428 & 33.1 \\
\hline no & 200 & 62.5 & 226 & $\mathbf{5 7 . 9}$ & $\mathbf{1 6 2}$ & $\mathbf{6 2 . 8}$ & $\mathbf{2 7 8}$ & $\mathbf{8 5 . 3}$ & $\mathbf{8 6 6}$ & $\mathbf{6 6 . 9}$ \\
\hline
\end{tabular}


Table (7): Body perception

\begin{tabular}{|c|c|c|c|c|c|c|c|c|c|c|c|}
\hline \multirow{2}{*}{} & \multicolumn{2}{|c|}{ Qalyobya } & \multicolumn{2}{|c|}{ Giza } & \multicolumn{2}{|c|}{ Cairo } & \multicolumn{2}{|c|}{ Monofya } & \multicolumn{2}{|c|}{ Total } & \multirow{2}{*}{ P value } \\
\cline { 2 - 9 } & No & $\%$ & No & $\%$ & No & $\%$ & No & $\%$ & No & $\%$ & \\
\hline $\begin{array}{c}\text { Know your } \\
\text { wt. }\end{array}$ & 91 & 28.4 & 117 & 30 & 62 & 24.2 & 99 & 30.6 & 369 & 28.6 & 0.335 \\
\hline $\begin{array}{c}\text { Know your } \\
\text { ht. }\end{array}$ & 14 & 4.4 & 34 & 8.8 & 15 & 5.9 & 42 & 13.5 & 105 & 8.3 & 0.000 \\
\hline $\begin{array}{c}\text { Body image } \\
\text { Good }\end{array}$ & 74 & 23.3 & 94 & 24.1 & 60 & 23.3 & 135 & 42.2 & 363 & 28.2 & 0.000 \\
Thin & 80 & 25.1 & 59 & 15.1 & 52 & 20.2 & 81 & 25.3 & 272 & 21.2 & \\
Overweight & 25 & 7.8 & 332 & 8.5 & 18 & 7 & 27 & 8.4 & 103 & 8 & \\
Don't know & 140 & 43.9 & 204 & 52.3 & 127 & 49.4 & 77 & 24.1 & 548 & 42.6 & \\
\hline
\end{tabular}


Table (8): Days of physical activity for more than $60 \mathrm{~min}$ a day in the past 7 days

\begin{tabular}{|c|c|c|c|c|c|c|c|c|c|c|c|}
\hline \multirow{2}{*}{} & \multicolumn{2}{|c|}{ Qalyobya } & \multicolumn{2}{|c|}{ Giza } & \multicolumn{2}{c|}{ Cairo } & \multicolumn{2}{c|}{ Monofya } & \multicolumn{2}{|c|}{ Total } & \multirow{2}{*}{ P value } \\
\cline { 2 - 11 } & No & $\%$ & No & $\%$ & No & $\%$ & No & $\%$ & No & $\%$ & \\
\hline None & 230 & 71.9 & 276 & 70.8 & 181 & 70.2 & 163 & 50 & 850 & 65.7 & \multirow{0}{*}{0.000} \\
\hline One & 27 & 8.4 & 44 & 11.3 & 49 & 19 & 53 & 16.3 & 173 & 13.4 & \\
\hline Two & 20 & 6.3 & 34 & 8.7 & 19 & 7.4 & 35 & 10.7 & 108 & 8.3 & \\
\hline Three & 16 & 5 & 16 & 4.1 & 7 & 2.7 & 30 & 9.2 & 69 & 5.3 & \\
\hline Four & 7 & 2.2 & 3 & 0.8 & 0 & 0 & 9 & 2.8 & 19 & 1.5 & \\
\hline Five & 9 & 2.8 & 11 & 2.8 & 2 & 0.8 & 24 & 7.4 & 46 & 3.6 & \\
\hline Six & 4 & 1.3 & 3 & 0.8 & 0 & 0 & 4 & 1.2 & 11 & 0.9 & \\
\hline Seven & 7 & 2.2 & 3 & 0.8 & 0 & 0 & 8 & 2.5 & 18 & 1.4 & \\
\hline
\end{tabular}


Table (9): Numbers of days you walk to and from School in past 7 days

\begin{tabular}{|c|c|c|c|c|c|c|c|c|c|c|c|}
\hline \multirow{2}{*}{} & \multicolumn{2}{|c|}{ Qalyobya } & \multicolumn{2}{|c|}{ Giza } & \multicolumn{2}{c|}{ Cairo } & \multicolumn{2}{c|}{ Monofya } & \multicolumn{2}{|c|}{ Total } & \multirow{2}{*}{ P value } \\
\cline { 2 - 11 } & No & $\%$ & No & $\%$ & No & $\%$ & No & $\%$ & No & $\%$ & \\
\hline None & 114 & 35.6 & 179 & 45.9 & 135 & 52.3 & 23 & 7.1 & 451 & 34.9 & \multirow{0}{*}{0.000} \\
\hline One & 11 & 3.4 & 11 & 2.8 & 7 & 2.7 & 24 & 7.4 & 54 & 4.1 & \\
\hline Two & 11 & 3.4 & 9 & 2.3 & 5 & 1.9 & 9 & 2.8 & 34 & 2.6 & \\
\hline Three & 12 & 3.8 & 24 & 6.2 & 5 & 1.9 & 16 & 4.9 & 57 & 4.4 & \\
\hline Four & 4 & 1.3 & 13 & 3.3 & 3 & 1.2 & 3 & 0.9 & 23 & 1.8 & \\
\hline Five & 149 & 46.6 & 150 & 38.5 & 150 & 38.5 & 245 & 75.2 & 645 & 49.8 & \\
\hline Six & 11 & 3.4 & 3 & 0.8 & 3 & 0.8 & 5 & 1.5 & 21 & 1.6 & \\
\hline Seven & 8 & 2.5 & 1 & 0.3 & 1 & 0 & 1 & 0.3 & 10 & 0.8 & \\
\hline
\end{tabular}


Table (10): Numbers of physical activity class per week

\begin{tabular}{|c|c|c|c|c|c|c|c|c|c|c|c|}
\hline \multirow{2}{*}{} & \multicolumn{2}{|c|}{ Qalyobya } & \multicolumn{2}{|c|}{ Giza } & \multicolumn{2}{c|}{ Cairo } & \multicolumn{2}{c|}{ Monofya } & \multicolumn{2}{c|}{ Total } & \multirow{2}{*}{ P value } \\
\cline { 2 - 11 } & No & $\%$ & No & $\%$ & No & $\%$ & No & \% & No & \% & \\
\hline None & $\mathbf{3 7}$ & $\mathbf{1 1 . 6}$ & $\mathbf{8 5}$ & $\mathbf{2 1 . 8}$ & $\mathbf{5 1}$ & $\mathbf{1 9 . 8}$ & $\mathbf{5 3}$ & $\mathbf{1 6 . 3}$ & $\mathbf{2 2 6}$ & $\mathbf{1 7 . 5}$ & $\mathbf{0 . 0 0 0}$ \\
\hline One & $\mathbf{2 6 6}$ & $\mathbf{8 3 . 1}$ & $\mathbf{2 7 7}$ & $\mathbf{7 1}$ & $\mathbf{2 0 0}$ & $\mathbf{7 7 . 5}$ & $\mathbf{2 5 7}$ & $\mathbf{7 8 . 8}$ & $\mathbf{1 0 0 0}$ & $\mathbf{7 7 . 3}$ & \\
\hline Two & $\mathbf{7}$ & $\mathbf{2 . 2}$ & $\mathbf{2 4}$ & $\mathbf{6 . 2}$ & $\mathbf{7}$ & $\mathbf{2 . 7}$ & $\mathbf{1 5}$ & $\mathbf{4 . 6}$ & $\mathbf{5 3}$ & $\mathbf{4 . 1}$ \\
\hline Three & $\mathbf{3}$ & $\mathbf{0 . 9}$ & $\mathbf{2}$ & $\mathbf{0 . 5}$ & $\mathbf{0}$ & $\mathbf{0}$ & $\mathbf{1}$ & $\mathbf{0 . 3}$ & $\mathbf{6}$ & $\mathbf{0 . 5}$ & \\
\hline Five or more & $\mathbf{7}$ & $\mathbf{2 . 2}$ & $\mathbf{2}$ & $\mathbf{0 . 5}$ & $\mathbf{0}$ & $\mathbf{0}$ & $\mathbf{0}$ & $\mathbf{0}$ & $\mathbf{9}$ & $\mathbf{0 . 7}$ & \\
\hline
\end{tabular}

Table (11): Is the benefits of physical activity at school?

\begin{tabular}{|c|c|c|c|c|c|c|c|c|c|c|c|}
\hline \multirow{2}{*}{} & \multicolumn{2}{|c|}{ Qalyobya } & \multicolumn{2}{|c|}{ Giza } & \multicolumn{2}{c|}{ Cairo } & \multicolumn{2}{c|}{ Monofya } & \multicolumn{2}{c|}{ Total } & \multirow{2}{*}{ P value } \\
\cline { 2 - 11 } & No & $\%$ & No & $\%$ & No & $\%$ & No & $\%$ & No & \% & \\
\hline yes & $\mathbf{7 2}$ & $\mathbf{2 2 . 5}$ & $\mathbf{1 4 8}$ & $\mathbf{3 8}$ & $\mathbf{8 7}$ & $\mathbf{3 3 . 7}$ & $\mathbf{1 5 0}$ & $\mathbf{4 6 . 2}$ & $\mathbf{4 5 7}$ & $\mathbf{3 5 . 4}$ & $\mathbf{0 . 0 0 0}$ \\
\hline No & $\mathbf{1 6 5}$ & $\mathbf{5 1 . 6}$ & $\mathbf{1 6 7}$ & $\mathbf{4 2 . 9}$ & $\mathbf{1 1 1}$ & $\mathbf{4 3}$ & $\mathbf{1 2 6}$ & $\mathbf{3 8 . 8}$ & $\mathbf{5 6 9}$ & $\mathbf{4 4}$ & \\
\hline I don't know & $\mathbf{8 3}$ & $\mathbf{2 5 . 9}$ & $\mathbf{7 4}$ & $\mathbf{1 9}$ & $\mathbf{6 0}$ & $\mathbf{2 3 . 3}$ & $\mathbf{4 9}$ & $\mathbf{1 5 . 1}$ & $\mathbf{2 6 6}$ & $\mathbf{2 0 . 6}$ & \\
\hline
\end{tabular}


Table (12): Duration of physical activity

\begin{tabular}{|c|c|c|c|c|c|c|c|c|c|c|c|}
\hline & \multicolumn{2}{|c|}{ Qalyobya } & \multicolumn{2}{|c|}{ Giza } & \multicolumn{2}{|c|}{ Cairo } & \multicolumn{2}{|c|}{ Monofya } & \multicolumn{2}{|c|}{ Total } & \multirow[t]{2}{*}{ P value } \\
\hline & No & $\%$ & No & $\%$ & No & $\%$ & No & $\%$ & No & $\%$ & \\
\hline$<1$ hour & 101 & 31.6 & 125 & 32.2 & 37 & 14.5 & 71 & 21.8 & 334 & 25.9 & 0.000 \\
\hline 1-2 hours & 193 & 60.3 & 197 & 50.8 & 146 & 57 & 208 & 64 & 744 & 57.7 & \\
\hline 3-4 hours & 23 & 7.2 & 53 & 13.7 & 56 & 21.9 & 46 & 14.2 & 178 & 13.8 & \\
\hline 5-6 hours & 3 & 0.9 & 11 & 2.8 & 14 & 5.5 & $\mathbf{0}$ & $\mathbf{0}$ & 28 & 2.2 & \\
\hline 7-8 hours & $\mathbf{0}$ & $\mathbf{0}$ & 1 & 0.3 & 2 & 0.8 & $\mathbf{0}$ & $\mathbf{0}$ & 3 & 0.2 & \\
\hline$>8$ hours & $\mathbf{0}$ & $\mathbf{0}$ & 1 & 0.3 & 1 & 0.4 & $\mathbf{0}$ & $\mathbf{0}$ & 2 & 0.2 & \\
\hline
\end{tabular}




\section{الوضع المتعلق بالمقصف المدرسي والأنشطة البدنية لاى عينة

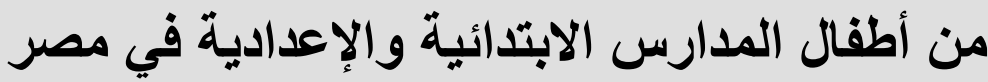

جيهان أحمد فؤاد- سلوي محمود صالح- مي كامل مطر - هدي مسعود الجزيري- اسماء السيد

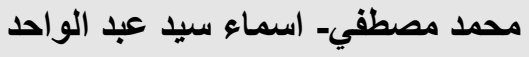

\section{الملخص العربي}

تأتي الأمراض غير المعدية عن طريق (نظام غذائس غير صحي ، وقلة النشاط البنسي ، وتعاطي

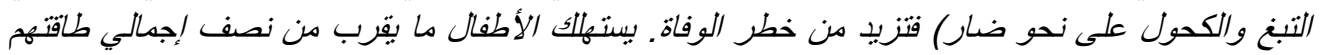

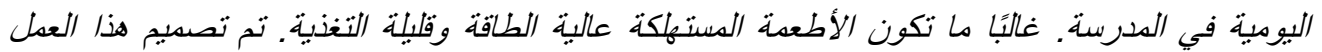

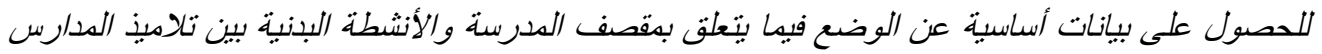

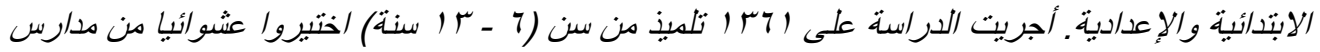

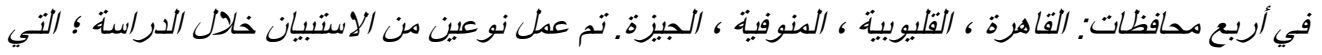

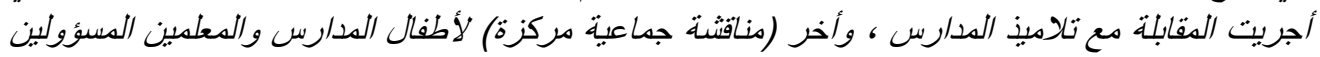

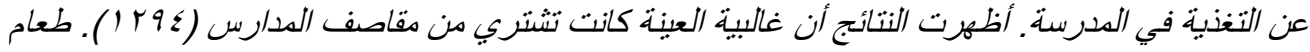

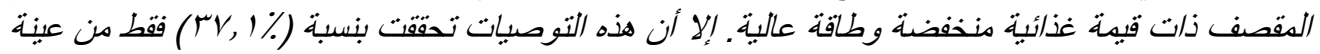

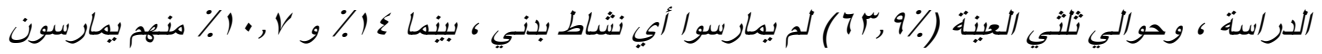

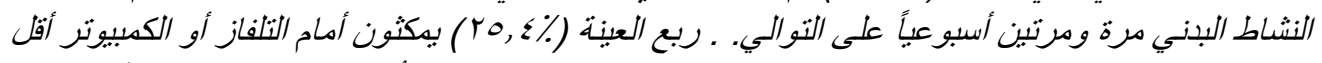

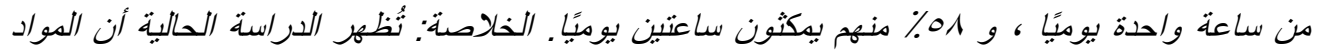

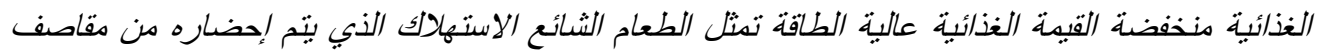

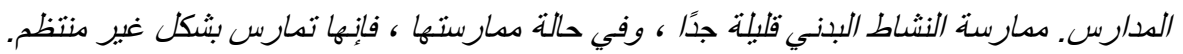

$$
\text { الكلمات المفتاحية: الددارس- المقصف ـ النشاط البنسي- الأمراض الغبر معديه }
$$

